\author{
Associate Professor Mircea Constantin DUICĂ, PhD \\ E- mail: mircea.duica@ valahia.ro \\ Management- Marketing Department \\ Valahia University of Targoviste \\ Lecturer Nicoleta Valentina FLOREA, PhD \\ E-mail: nicoleta.florea@valahia.ro \\ Management- Marketing Department \\ Associate Professor Anișoara DUICĂ, PhD \\ E- mail: anisoara.duica@valahia.ro \\ Management- Marketing Department \\ Associate Professor Dan Marius COMAN, PhD \\ E-mail: marius.coman@valahia.ro \\ Finance-Accounting Department
}

\title{
THE RELATIONSHIP BETWEEN ECONOMIC ACTIVITY AND GREEN PRODUCTION AND CONSUMPTION AT EU LEVEL. AN ANALYSIS BASED ON ECONOMETRIC AND INFORMATION MODELS
}

Abstract. In today economic environment, green consumption and production became two vectors of performance on long run. To have green consumers must be also existing green producers and also green supply chains because the war for profitability and satisfying consumers is between supply chains. Green environment is obtained through green attitudes, green thinking, green behavior of consumers and producers, of organizations, and governments. Consuming resources is affecting environment and the limited resources, and for this reason our article presents the importance of sustainable consumption and production at EU level. This article is based on using an econometric model regression function and information model in order to observe that there is a relationship between the sustainable production and consumption variables presented in EU statistics and its economic factors of influence, variables which are affecting the future life, future generations, and future activities. This mathematical function showed a direct, positive and strong relationship $(0.938$, being very close to 1), which must be analyzed in order to observe future influences, risks and measures to diminish its impact on organizations performance and also on global environment.

Keywords: Econometric model, Sustainable Consumption, Green production, Regression Function, Long-Term Performance.

JEL Classification: B23, C15, C87, E27, F47 
Mircea Constantin Duică, Nicoleta Valentina Florea, Anișoara Duică, Dan Marius Coman

\section{Introduction}

Mathematical modelling is used in every field in order to observe trends and take some useful measures for individuals, organizations, areas, or countries, but is used even in green economic field. Since 1960s a special attention was given for environmental problems (Telesiene \& Gross, 2016, p.1), for green economy since 2000s (Shmelev, 2016, p.143) and also for changes in policies, regulations, rules, and many studies for a greener lifestyle, greener innovations (Peiry, Ziegler \& Baumgartner, 2016, p.xv).

Environmental consciousness is not only an ideology but a problem of „market competition", which it had impact on consumer' behavior. Becoming a ,green consumer" is important for the whole supply chain, paying more for ,green products". Malyan \& Duhan (2018) add that green marketing is not just another term for profitability use, is also a social and environmental dimension, which must be regarded with maximum attention for future life.

The chapter begins to present the literature in the green field by offering some insights of different specialists from the sustainable consumption and production domain. Then, is offered information about being green, having a green behavior as individual and as organization. In this article are presented the sustainable consumption and production and then are described the factors with great influence on these two processes, factors considered by EU as having great impact on green future. Thus, the authors, starting with this idea, they used data from EU-27 level (statistics and reports) in order to analyze the correlation between the analyzed variables, the distribution, and the impact could have using a mathematical function (regression function), descriptive statistics, OLS, distribution of residuals and the correlation matrix, but also an IT program, as Eviews7.

The readers will be interested in this chapter due to the use and benefits of mathematical modelling and simulation programs necessary to determine from time future risks, impact and problems caused by the consumption and production processes on future health and environment evolution.

\section{The green production}

\subsection{Definition and role}

Green production is an interesting topic, not only for economic studies but also for describing „environmental stress” all over the world. Green production, besides its benefits for environment and for society, represents a strategic decision for organizations, and especially for the manufacturers, no matter the domain or the size, and an important problem for governments (Sang-Binge, Bin L. \& Yongian, 2017, p.281). The green needs of consumers pushed the organization to invest in green production, and is not just a desire, but a challenge in order to achieve the competitive advantage or to grow in a global market. 
The Relationship between Economic Activity and Green Production and Consumption at EU Level. An Analysis Based on Econometric and Information Models

In order to promote the integration of environmental costs associated with goods throughout their life cycles into the market price of products, organizations developed the Extended Producer Responsibility (EPR) strategy. This strategy helped explore the decision mechanism for green production and the governance mechanism of green supply chain (Sang-Binge, Bin, \& Yongian, 2017).

Future decisions of green consumers will influence the price and the quality but also the social and environmental factors, such as: reducing the carbon-footprint, using sustainable technologies for sustainable production and processing and decreasing their environmental and health impacts

\subsection{Green production benefits}

Green production will not be implemented without commitment of top management and lieder: it has many benefits: acts as vital link between suppliers and customers, helps organizations to become more responsible, prevents pollution, brings technological innovations, helps reduce waste at each stage of the production cycle, lowers regulatory costs, reduces consumption of raw material and energy, reduces medical expenses with employees, consumers and public, improve human health: reduce diseases and improve antioxidative activity (Hara, Yang, Isemura \& Tomita, 2017, p.21), inter-generational equity, employment in a greener environment, strengthen the social wefare (Mangla \& Luthra, 2019, p.vii).

\subsection{Green production behaviour}

In today globalized world many organizations are involved in developing new green products to satisfy green consumers and their green needs, becoming green organizations: Toyota Prius made the first car with a green platform from its inception (Iannuzzi, 2016, p.6), Starbucks Corporation used green marketing to strengthen its brand and image among consumers (Malyan \& Duhan, 2018), H\&M, Marks\&Spencer and Levis have taken many approaches to minimize environmental pollution by introducing in their processes the use of new technologies (Sang-Binge, Bin \& Yongian, 2017, p.281), Ford Motor Company improve its image with ten-part environmental policy; its vehicles are $80 \%$ recyclable; (Malyan \& Duhan, 2018), The Walt Disney Company uses a zero greenhouse gas emissions by reducing electrical consumption (Malyan \& Duhan, 2018) and Nike, Inc. apply green initiatives in its advertising.

To have a better life for individuals, society and planet, the answer could be, says Ekstrom (2014, p.5) in making green products with people having different knowledge and experience and preventing waste, managing it adequate or even zero waste by implementing a circular economy. 
Mircea Constantin Duică, Nicoleta Valentina Florea, Anișoara Duică, Dan Marius Coman

\section{The green consumption}

\subsection{The green consumer}

In today era, the green consumers are considered for market place as important part for decision making, thus they can no longer be separated from environmental issues (Thangasamy, 2017, p.121).

The green consumer movement began in Europe and spread to North America. Thus, the supermarkets were forced to listen the voice of green customers and remove the products with pesticide residues or cars with recyclable components. A whole new category of green business and green products appeared in different fields, such as cosmetics, electrical goods or even cars.

Consumer choices, as important factors of societal functioning, are influencing production and also impacting the environment (Boucher \& Heinonen, 2019, p.2).

\subsection{Consumption and waste}

Sustainable consumption is not only about satisfaying the consumers needs and protecting the environment, is also an important strategy for achieving poverty alleviation (UN Environment Programme, 2005, p.14). This strategy can help them, by using recyclable system, sustainable products, organic food, adopting green procurement, or avoid waste dumping.

Besides other initiatives, social movements are a key in solving sustaining issues (Boucher \& Heinonen, 2019) and social responsibility of organizations and buying second-hand goods, such as: cars, charity shops and auction sales (Ekstrom, 2014, p.5). Consumption is the motor of waste production. To understand waste we have to understand consumption. To help consumers to ramain green or to become green must (UN Environment Programme, 2005, p.10): implement new technologies, develop environmentally friendly products or develop recycling programmes for waste management.

\section{The factors considered with great impact on sustainable production and consumption}

Sustainable development objectives have been at the heart of European policy for a long time (Sustainable Development in the EU, 2019, p.9). EU Report contain 17 SDGs (Sustainable Development Goals) and we analyze the content of SDG12, which refers to responsible consumption and production. Its main analyzed factors are: resource and energy productivity, circular material use and recycling, renewable energy, primary energy, $\mathrm{CO}_{2}$ emissions, consumption of toxic chemicals.

\subsection{Circular material use rate}

The indicator measures the share of material recovered and fed back into the economy. Using natural resources more efficiently, we can live healthier lives, save

DOI: 10.24818/18423264/55.2.21.20 
The Relationship between Economic Activity and Green Production and Consumption at EU Level. An Analysis Based on Econometric and Information Models

money, create jobs, boost our economy and respect the limits of the planet (https://ec.europa.eu/environment/green-growth/index_en.html).

In 2016, 905 million tons of waste were generated, corresponding to 1772 kilograms of waste per EU inhabitant. When not managed sustainably, the waste could negative influence environment and human health (European Commission, 2010). Despite a considerable increase over the past decade, recycling rates of municipal waste remained below $50 \%$ in the EU (46.4\% in 2017) (Eurostat, sdg_11_60). This is because landfill and incineration are the dominant treatment operations for municipal waste. We may observe in the graph below the increasing trend of circular material use for EU-27, at Romanian level the values are decreasing, so the consumption of resources is bigger (Graph 1).

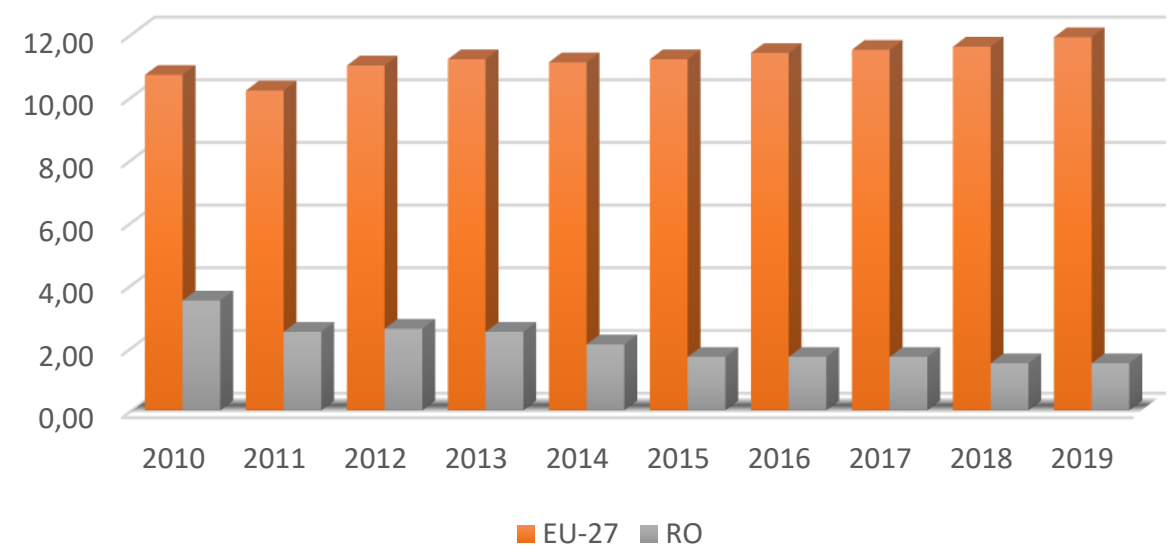

Graph 1. Circular material use rate (\% of total material use)

Source:

https://ec.europa.eu/eurostat/databrowser/view/cei_srm030/default/table?lang=en

\section{2. $\mathrm{CO}_{2}$ emissions}

The European Union is proud on having some of the highest environmental standards in the world (Environment, European Union, 2018). In 2015, the total greenhouse gas emissions (GHG) in EU were lower with 22\% compared with the levels from 1990. A study made by European Commission (https://europa.eu/european-union/topics/environment_en) showed that in 2016, cars were responsible for around $14 \%$ of total $\mathrm{EU}$ emissions of $\mathrm{CO} 2$, and in order to reduce the negative impact on the environment its main targets were established for each manufacturer's new car fleet, a specific emission target; that from 130 grams per kilometer $(\mathrm{g} / \mathrm{km}$ ) in 2015 to get to $95 \mathrm{~g} / \mathrm{km}$ in 2021 (European Parliament and Council of the European Union, 2009). Data show that this emission reduced from $10.4 \%$ since 2012 , to $118.5 \mathrm{~g} / \mathrm{km}$ in 2017 . Continuous emissions of GHG may cause irreversible changes and impacts on human life and ecosystems.

DOI: $10.24818 / 18423264 / 55.2 .21 .20$ 
Mircea Constantin Duică, Nicoleta Valentina Florea, Anișoara Duică, Dan Marius Coman

\subsection{Energy productivity}

Results from the division of the gross domestic product (GDP) by the gross available energy for a given calendar year and it measures the productivity of energy consumption and provides an image of the degree of decoupling of energy use from growth in GDP.

Over the past few years, at EU level and also at Romanian level (Graph 3), these analyzed indicators indicate some progress, so, resource and energy productivity has risen, and consumption of hazardous chemicals and $\mathrm{CO}_{2}$ emissions have reduced (due to the new cars developed). Europe 2020 strategy highlights the need of smart, sustainable and inclusive growth while also reducing energy consumption

\subsection{Resource productivity}

Part of the Europe 2020 Strategy, for a smart, inclusive and sustainable economy, the Roadmap to a Resource-Efficient Europe propose a few methods in order to increase resource productivity and decouple economic growth from resource use and its environmental impact. The Commission also focus on improving resource efficiency in more specific areas, such as in the food sector, building, SMEs sector and to turn the waste into a resource. (https://ec.europa.eu/environment/greengrowth/index_en.html). Between 2002 and 2017, in EU the resource productivity increased by $34.7 \%$, in 2017 , and its energy productivity by $29.7 \%$. This increasing is due to the growth of the EU economy and to reductions in domestic material consumption (Sustainable Development in the EU, 2019, p.235).

\subsection{Renewable energy}

This objective allows for also economic growth and also reduce the environmental impacts and costs linked to energy supply and use. Therefore, the EU to improve energy efficiency by $20 \%$ and to increase its share of renewable energy to $20 \%$ of energy consumption by 2020. To measure progress towards energy efficiency, the target has been translated into absolute target values for primary energy consumption (1 483 million tons of oil equivalent (Mtoe)) and final energy consumption (1086 Mtoe) for 2020. In 2017, 1561.6 Mtoe of primary and 1122.8 Mtoe of final energy were consumed. Analyzing on long-term (2002-2017), the consumption of primary and final energy fell by $5.8 \%$ and $2.0 \%$ and in the short term (since 2012), final energy consumption has risen by $1.1 \%$.

The share of renewables, increased in EU from $8.5 \%$ in 2004 to $17.5 \%$ in 2017, but are demanded more efforts to achieve the objective of $20 \%$ by 2020 (Graph 2). Most countries (EU-27) presented waste management and recycling initiatives as the core of their national approach to material resource efficiency (http://www.sepa.gov.rs/download/publikacije/MoreFromLess MaterialResourceE fficiencyEurope.pdf 
The Relationship between Economic Activity and Green Production and Consumption at EU Level. An Analysis Based on Econometric and Information Models

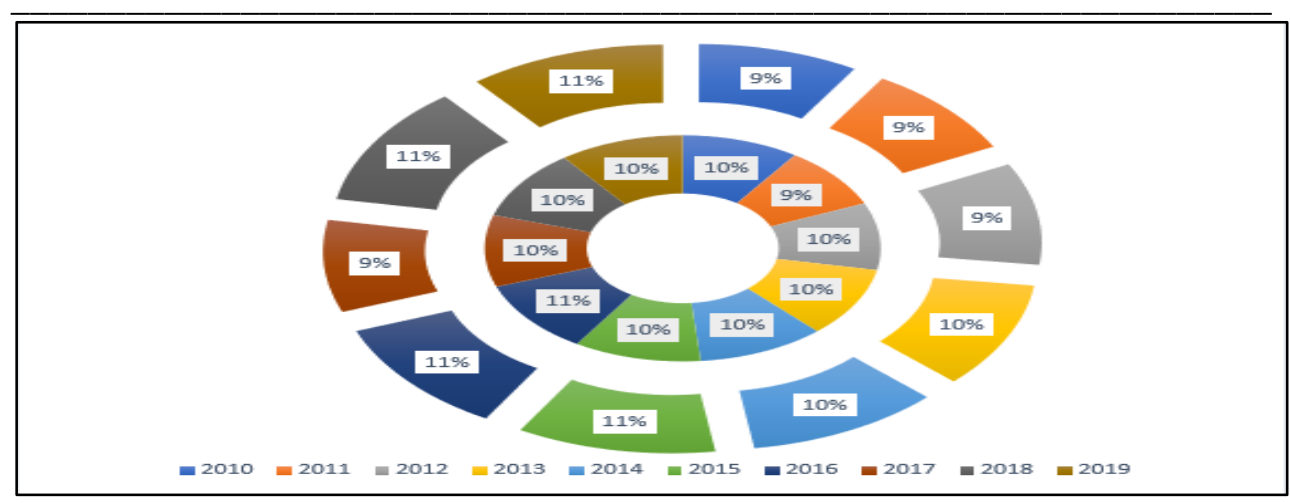

Graph 2. Share of energy from renewable sources

Source:

https://ec.europa.eu/eurostat/databrowser/view/nrg_ind_ren/default/table?lang=en

\subsection{Primary energy consumption}

The consumption of energy is a vital condition for the functioning and growth of European economies. But its increasing will harm the environment. To reduce the negative effects, the EU focus on using energy more efficiently or to change it by using renewable energy sources. At EU-27 level and Romanian level are known decreasing values between 2010 and 2019; the more reduced values were obtained in 2014 and in 2019 (Graph 3).

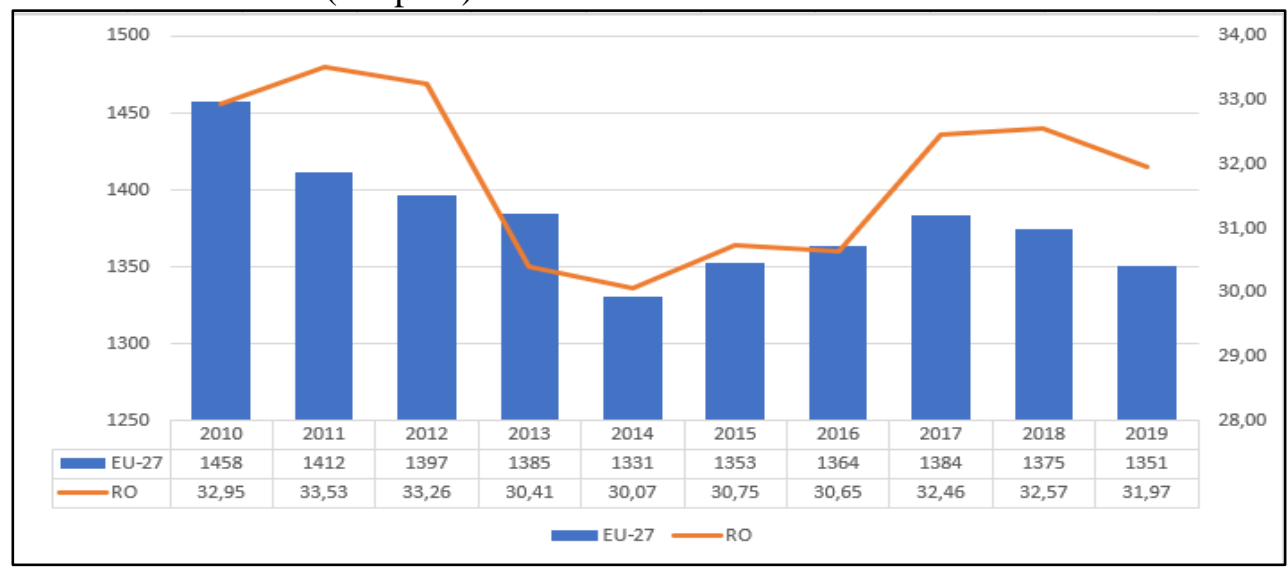

Graph 3. Primary energy consumption

Source:

https://ec.europa.eu/eurostat/databrowser/view/t2020_33/default/table?lang=en

The 7th Environment Action Program (EAP) will guide European environment policy until 2020, offering long-term direction, a vision by 2050, and identifies three important objectives: to protect, conserve and enhance the Union's natural capital, to turn into a resource-efficient, green, and competitive low-carbon

DOI: 10.24818/18423264/55.2.21.20 
Mircea Constantin Duică, Nicoleta Valentina Florea, Anișoara Duică, Dan Marius Coman

economy, and to safeguard the Union's citizens from environment-related pressures and risks to health and wellbeing

(https://ec.europa.eu/environment/action-programme/).

\subsection{Consumption of chemicals}

Most products used by organizations and customers are made using chemicals. Chemicals are used in agriculture, pharmacies, detergents, cosmetics, textiles, buildings or packaging, contributing to the EU economy, with sales worth EUR 542 billion in 2017 (The European Chemical Industry Council, 2018).

Their use brought benefits but also risks for society and environment. 2012-2016 was a period for reduction of consumption of chemicals; 2019 is the year with lowered consumption and increased interest in reducing it. The studies show that in 2017, 307.9 million tons of chemicals were consumed in the EU, and $22.3 \%$ are considered harmful to the environment and $71.4 \%$ as harmful for human health (European Environment Agency, 2018).

\section{Research methodology}

Economic activity development was linked by the consumption of resources and energy. Natural resources help develop economy and quality of life, but the future population growth (around 9 million in 2050) and the consumption levels will put a pressure on resources. Continuing this trend, this pattern is not an option. Thus, its concentration is on improving resource- and energy-use efficiency by restructuring economies so they produce more from the same resource and energy inputs and minimizing the impact on environment. Despite this efficiency, the rise of population around the world and of the wealth per-capita make the consumption growing and this task difficult, but not impossible.

Our study is based on consumption and production from a green point of view at EU-27 level.

The EU's progress in this area is monitored by four indicators:

1. two indicators look at the ratio of resource use (materials and energy) to GDP,

2. while the other two looks at the harmful environmental impacts of consumption of toxic chemicals and $\mathrm{CO} 2$ emissions related to transport.

As we may observe, there are a few factors with real impact on human health, environment and society. To analyze the impact and the relationship between the analyzed variables, it was used a regression function, in order to observe the intensity of impact and the correlation between these chosen factors.

\section{Objectives}

The article is analyzing the relationship between the economic activity and the green production and consumption, using a regression function. The research was made using data and information from EU-27 level (Eurostat.com) and different EU reports. 
The Relationship between Economic Activity and Green Production and Consumption at EU Level. An Analysis Based on Econometric and Information Models

Tools for data collection: observation and data analysis using mathematical modelling techniques and E-views program.

Tools for analysis:

- Descriptive Statistics (to find out the normal distribution of the series),

- Linear Regression Model (OLS to test the impact of independent variables on dependent variable),

- Distribution of residuals (to find out the distribution of the series),

- Correlation Matrix (to find the correlation between the analyzed variables).

The method used, regression method, allowed us to make predictions, in our case to estimate the value of $\mathrm{y}$ variable when are associated variable $\mathrm{x}_{1}-\mathrm{x}_{6}$ values, and, if the chosen variables are associated and what degree of association exists between them.

$y=a_{0}+a_{1} * x_{1}+a_{2} * x_{2}+\cdots+a_{6} * x_{6}+z$

Where [Dinulescu, Smeureanu, Dobrin \&Popa, 2018, p.64]:

$\mathrm{y}=$ dependent variable (circular material use rate),

$\mathrm{x}_{1}-\mathrm{x}_{6}=$ independent variables (the factors considered by EU as factors which influence the dependent variable.

$\mathrm{x}_{1}-\mathrm{CO}_{2}$ emissions, $\mathrm{x}_{2}$-energy productivity, $\mathrm{x}_{3}{ }^{-}$share of renewable energy, $\mathrm{x}_{4-}$ primary energy consumption, $\mathrm{x}_{5^{-}}$resource productivity and domestic material consumption (DMC) and $\mathrm{x}_{6}$ - consumption of chemicals),

$\mathrm{a}_{1}-\mathrm{a}_{6}=$ the slope (or gradient) of the straight line, and $\mathrm{a}_{0}=$ the intercept,

$z=$ residual term, capturing all non-regressor factors influence.

Data were collected from EU-27 level (the 27 countries from EU) and were gathered between 2010 and 2018 (Table 1) and analyzed using the econometric tools which were remembered above.

Table 1. Data about responsible consumption and production in the $\mathbf{E U}$

\begin{tabular}{|l|l|l|l|l|l|l|c|}
\hline Year & $\begin{array}{l}\text { Circular } \\
\text { material } \\
\text { use rate } \\
(\mathbf{y})\end{array}$ & $\begin{array}{l}\text { CO2 } \\
\text { emissions } \\
(\mathbf{x 1})\end{array}$ & $\begin{array}{l}\text { Energy } \\
\text { produc- } \\
\text { tivity } \\
(\mathbf{x 2})\end{array}$ & $\begin{array}{l}\text { Share of } \\
\text { renewable } \\
\text { energy in } \\
\text { gross final } \\
\text { energy }(\mathbf{x 3})\end{array}$ & $\begin{array}{l}\text { Primar } \\
\text { energy } \\
\text { consum- } \\
\text { ption } \mathbf{( x 4 )}\end{array}$ & $\begin{array}{l}\text { Resource } \\
\text { produc- } \\
\text { tivity and } \\
\text { DMC } \\
(\mathbf{x 5})\end{array}$ & $\begin{array}{l}\text { Consumption of } \\
\text { chemicals hazardous } \\
\text { to the environment } \\
(\mathbf{x 6})\end{array}$ \\
\hline 2010 & 10.8 & 140.3 & 7.1 & 13118 & 1163.13 & $1 . .8474$ & 88.2 \\
\hline 2011 & 11.0 & 135.7 & 7.4 & 13374 & 1110.65 & 1.7939 & 85.5 \\
\hline 2012 & 10.6 & 132.2 & 7.5 & 14678 & 1110.62 & 1.9314 & 80.7 \\
\hline 2013 & 11.3 & 126.7 & 7.6 & 15402 & 1110.57 & 1.9771 & 80.4 \\
\hline 2014 & 11.5 & 123.4 & 8.0 & 16190 & 1065.57 & 1.9839 & 80.8 \\
\hline 2015 & 11.4 & 119.5 & 8.1 & 16716 & 1088.27 & 2.0259 & 78.5 \\
\hline 2016 & 11.4 & 118.1 & 8.2 & 17021 & 1110.08 & 2.0735 & 75.2 \\
\hline 2017 & 11.7 & 118.5 & 8.3 & 17526 & 1122.77 & 2.0718 & 73.8 \\
\hline 2018 & 11.7 & 118.5 & 8.3 & 17526 & 1122.77 & 2.0437 & 76.4 \\
\hline
\end{tabular}

https://ec.europa.eu/eurostat/statistics-explained/index.php?title=SDG_12 -

Responsible_consumption_and_production_in_the_EU:_overview_and_key_trends

DOI: 10.24818/18423264/55.2.21.20 
Mircea Constantin Duică, Nicoleta Valentina Florea, Anișoara Duică, Dan Marius Coman

\section{Descriptive statistics}

Regarding the data (Table 2), it is observed that $\mathrm{x} 1, \mathrm{x} 4, \mathrm{x} 6$ are positively skewed but the other variables are negatively skewed (the distribution is left-skewed).

The difference between the mean value and the median is not high, or low.

For kurtosis, its values are between 1.69 and 2.242 being below the benchmark of a normal distribution, and only a single value is above 3 (for $\mathrm{x} 4-3.43$ ) which is positioned near normality. The values of kurtosis are below 3 (exception just one value), but bigger than 0 , making the distribution Leptokurtic and the values are putted around the central tendency.

Thus, the variables are characterized by a normal distribution. Jarque-Bera for the analyzed variables is indicating that values are normally distributed. So, is showing that there is a normal distribution among the analyzed variables.

\section{Table 2. Descriptive statistics}

\begin{tabular}{|c|c|c|c|c|c|c|c|}
\hline & $\begin{array}{c}\text { Circular } \\
\text { material } \\
\text { use rate (y) }\end{array}$ & $\begin{array}{c}\text { CO2 } \\
\text { emis- } \\
\text { sions } \\
\mathbf{( x 1 )}\end{array}$ & $\begin{array}{c}\text { Energy } \\
\text { product } \\
\text { ivity } \\
\mathbf{( x 2 )}\end{array}$ & $\begin{array}{c}\text { Share of } \\
\text { renewable } \\
\text { energy in } \\
\text { gross final } \\
\text { energy (x3) }\end{array}$ & $\begin{array}{c}\text { Primar } \\
\text { energy } \\
\text { consum- } \\
\text { ption (x4) }\end{array}$ & $\begin{array}{c}\text { Resource } \\
\text { productivity } \\
\text { and DMC } \\
\mathbf{( x 5 )}\end{array}$ & $\begin{array}{c}\text { Consumption of } \\
\text { chemicals hazardous } \\
\text { to the environment } \\
\mathbf{( x 6 )}\end{array}$ \\
\hline Mean & 11.266 & 125.87 & 7.83 & 15727.89 & 1111.603 & 1.97 & 79.94 \\
\hline Median & 11.4 & 123,4 & 8 & 16190 & 1110.62 & 1.98 & 80.4 \\
\hline Maximum & 11.7 & 140.3 & 8.3 & 17526 & 1163.13 & 2.07 & 88.2 \\
\hline Minimum & 10.6 & 118.1 & 7.1 & 13118 & 1065.57 & 1.79 & 73.8 \\
\hline Std. Dev. & 0.387 & 8.37 & 0.44 & 1691.495 & 26,39 & 0.098 & 4.68 \\
\hline Skewness & -0.54 & 0.59 & -0.38 & -0.47 & 0.211 & -0.71 & 0.45 \\
\hline Kurtosis & 2.02 & 1.86 & 1.69 & 1.769 & 3.43 & 2.242 & 2.24 \\
\hline Jarque-Bera & 0.79 & 1.01 & 0.85 & 0.898 & 0.139 & 0.97 & 0.51 \\
\hline Probability & 0.67 & 0.6 & 0.65 & 0.637 & 0.932 & 0.61 & 0.77 \\
\hline Sum & 101.4 & 1132.9 & 70.5 & 141551 & 10004.43 & 17.74 & 719.5 \\
\hline Sum Sq. Dev. & 1.2 & 561.29 & 1.56 & 22889237 & 5573.163 & 0.077 & 175.44 \\
\hline Observations & 9 & 9 & 9 & 9 & 9 & 9 & 9 \\
\hline
\end{tabular}

Calculations made by the authors using Eviews7.

\section{Correlation}

Using E-views program it was obtained the correlation matrix (Table 3).

If the obtained values are negative, then the correlation is wick and that they are not related, if the values are over 0 , the relations are positive and strong and if there are closer to one, means that the two variables are very strongly related to each other.

So, the correlations between the analyzed variables are positive and negative as follows:

- negative correlations:

- but weak: are between resource productivity and primary energy consumption $(-0.301)$, primary energy and circular material use rate $(-0.33)$, 
The Relationship between Economic Activity and Green Production and Consumption at EU Level. An Analysis Based on Econometric and Information Models

- Primary energy consumption and share of renewable (-0.38), primary energy consumption and energy productivity $(-0.43)$.

- but strong: are between $\mathrm{CO} 2$ emissions and energy productivity (-0.97), resource productivity and consumption of chemicals (-0.93), energy productivity and consumption of chemicals (-0.92), CO2 emissions and circular material use rate $(-0.86)$,

- positive correlations:

- but weak: are between primary energy consumption and $\mathrm{CO} 2$ emissions (0.47), consumption of chemicals and primary energy consumption (0.31).

- but strong: are between share of renewable energy and energy productivity (0.97), resource productivity and share of renewable energy in gross final energy (0.96), consumption of chemicals and $\mathrm{CO} 2$ emissions (0.93), resource

productivity and energy productivity (0.905), energy productivity and circular material use rate $(0.87)$, share of renewable energy in gross final energy (0.85), resource productivity and DMC and circular material use rate (0.75).

Table 3. The correlation matrix between the analyzed variables

\begin{tabular}{|c|c|c|c|c|c|c|c|}
\hline Variables & $\begin{array}{l}\text { Circular } \\
\text { material } \\
\text { use rate } \\
(\mathbf{y})\end{array}$ & $\begin{array}{l}\mathrm{CO} 2 \\
\text { emis- } \\
\text { sions }(\mathbf{x 1})\end{array}$ & \begin{tabular}{|l|} 
\\
Energy \\
produc- \\
tivity (x2)
\end{tabular} & $\begin{array}{l}\text { Share of } \\
\text { renewable } \\
\text { energy in } \\
\text { gross final } \\
\text { energy } \\
\text { (x3) }\end{array}$ & $\begin{array}{l}\text { Primar } \\
\text { energy } \\
\text { consump- } \\
\text { tion (x4) }\end{array}$ & $\begin{array}{l}\text { Resource } \\
\text { productivi } \\
\text { ty and } \\
\text { DMC (x5) }\end{array}$ & $\begin{array}{l}\text { Consumption } \\
\text { of chemicals } \\
\text { hazardous to } \\
\text { the } \\
\text { environment } \\
\text { (x6) }\end{array}$ \\
\hline $\begin{array}{l}\text { circular material } \\
\text { use rate }(\mathbf{y})\end{array}$ & 1 & & & & & & \\
\hline $\begin{array}{l}\text { CO2 emissions } \\
(\mathbf{x 1})\end{array}$ & -0.86 & 1 & & & & & \\
\hline $\begin{array}{l}\text { energy } \\
\text { productivity (x2) }\end{array}$ & 0.87 & -0.97 & 1 & & & & \\
\hline $\begin{array}{l}\text { share of renewable } \\
\text { energy in gross } \\
\text { final energy }(\mathbf{x} 3)\end{array}$ & 0.85 & -0.98 & 0.97 & 1 & & & \\
\hline $\begin{array}{l}\text { primar energy } \\
\text { consumption }(\mathrm{x} 4)\end{array}$ & -0.33 & 0.47 & -0.43 & -0.38 & 1 & & \\
\hline $\begin{array}{l}\text { resource } \\
\text { productivity and } \\
\text { DMC (x5) }\end{array}$ & 0.75 & -0.94 & 0.905 & 0.96 & -0.301 & 1 & \\
\hline $\begin{array}{l}\text { consumption of } \\
\text { chemicals } \\
\text { hazardous to the } \\
\text { environment (x6) }\end{array}$ & -0.73 & 0.93 & -0.92 & -0.94 & 0.31 & -0.93 & 1 \\
\hline
\end{tabular}

Calculations made by the authors using Eviews7.

DOI: $10.24818 / 18423264 / 55.2 .21 .20$ 
Mircea Constantin Duică, Nicoleta Valentina Florea, Anișoara Duică, Dan Marius Coman

As we may observe dependent variable (circular material use rate- y) is positive and strong influenced by energy productivity $(0,87)$, renewable energy $(0.85)$, and resource productivity $(0.75)$ and negative and strong by $\mathrm{CO} 2$ emissions $(-0.86)$ and consumption of chemicals $(-0.73)$, and negative but weak by primary energy consumption (-0.33).

It is important to find other ways to develop new products or services, to reduce inputs, decrease waste, to well manage resource stocks, change consumption patterns, to optimize production processes, management and business methods, and improve logistic. In order to have a good quality of life and not to reduce the natural resources, the EU fight to become a resource-efficient, green and competitive low-carbon economy (Eurostat).

\section{OLS regression}

Using E-views it was obtained the following results for OLS regression method. According to the literature in the field, $\mathrm{R}$ taking values between 0.7 and 0.9 are high correlated. Making the calculation of OLS method was obtained for $\mathrm{R}^{2}=0.88$ (Table 4).

Table. 4 OLS method

\begin{tabular}{|c|c|c|c|c|}
\hline \multicolumn{4}{|c|}{ Dependent Variable: circular material use rate $(\mathrm{y})$} & \\
\hline \multicolumn{5}{|c|}{ Method: Least Squares } \\
\hline \multicolumn{5}{|l|}{ Included observations: 7} \\
\hline Variable & Coefficient & Std. Error & t-Statistic & Prob. \\
\hline $\mathrm{CO} 2$ emissions $(\mathrm{x} 1)$ & -0.066 & 0.09 & -0.72 & 0.54 \\
\hline energy productivity (x2) & -0.414 & 1.83 & -0.22 & 0.84 \\
\hline $\begin{array}{l}\text { share of renewable energy in gross } \\
\text { final energy }(\mathrm{x} 3)\end{array}$ & 0.0004 & 0.00066 & 0.63 & 0.59 \\
\hline primary energy consumption $(\mathrm{x} 4)$ & 0.003 & 0.005 & 0.74 & 0.53 \\
\hline $\begin{array}{l}\text { resource productivity and DMC } \\
(\mathrm{x} 5)\end{array}$ & -4.69 & 6.131 & -0.76 & 0.52 \\
\hline $\begin{array}{l}\text { consumption of chemicals } \\
\text { hazardous to the envir. (x6) }\end{array}$ & 0.058 & 0.068 & 0.86 & 0.47 \\
\hline $\mathrm{C}$ & 16.67 & 26.97 & 0.61 & 0.59 \\
\hline R-squared & 0.88 & \multicolumn{2}{|c|}{ Mean dependent var } & 11.26 \\
\hline Adjusted R-squared & 0.55 & \multicolumn{2}{|c|}{ S.D. dependent var } & 0.38 \\
\hline S.E. of regression & 0.25 & \multicolumn{2}{|c|}{ Akaike info criterion } & 0.19 \\
\hline Sum squared $\mathrm{r}$ & 0.134 & \multicolumn{2}{|c|}{ Schwarz criterion } & 0.34 \\
\hline Log likelihood & 0.136 & \multicolumn{2}{|c|}{ Hannan-Quinn criter. } & -0.13 \\
\hline F-statistic & 2.63 & \multicolumn{2}{|c|}{ Durbin-Watson stat } & $2.6 \mathrm{t}$ \\
\hline $\operatorname{Prob}($ F-statistic) & 0.30 & & & \\
\hline
\end{tabular}

Calculations made by the authors using Eviews7. 
The Relationship between Economic Activity and Green Production and Consumption at EU Level. An Analysis Based on Econometric and Information Models

$\mathrm{R}$-squared is 0.88 , thus, $\mathrm{R}$ becomes 0.938 showing that between the analyzed variables there is a positive and very high correlation and that $93.8 \%$ of the evolution of variable $\mathrm{Y}$ is explained by the evolution of chosen $\mathrm{X}$ factors.

Estimation equation and substituted coefficients:

$\mathrm{Y}=16,67-0,066 * \mathrm{X} 1-0,4149 * \mathrm{X} 2+0,0004 * \mathrm{X} 3+0,003 * \mathrm{X} 4-4,69 * \mathrm{X} 5+0.058 * \mathrm{X} 6+$ 乙

To increase with a monetary unit y will get a decrease of 0.0066 monetary units of $\mathrm{X} 1$, a decrease of 0.4149 m.u of X2, an increase with 0.0004 m.u. of X3, an increase with 0.003 m.u. of X4, a decrease with 4.69 m.u. of X5, and an increase with 0.058 m.u. of X6.

It is observing that the value of free term (16.67) is enough high to conclude that the factors taken into account in the model construction have an important impact on the evolution of y (being positive). Having positive value, the free term shows that the variables chosen for the econometric model have a positive effect on the evolution of y. The Durbin Watson statistic of 2.6 shows evidence of autocorrelation. Thus, it was demonstrated that between the analyzed variables there is a positive and very strong relation ( $\mathrm{R}$ being very close to 1 ).

\section{Distribution of residuals}

The figure below is showing the distribution of residuals. The output presents the distribution histogram: mean, median, maximum and minimum values, standard deviation, skewness, kurtosis, and Jarque-Bera (Table 5).

Table 5. The distribution histogram of residuals

\begin{tabular}{|l|r|r|}
\hline Intervals between: & Value & Residuals for 9 observations \\
\hline$(-0.20)-(-0.15)$ & 2 & Mean is $-4.74 \mathrm{e}-15$ \\
\hline$(-0.15)-(-0.10)$ & 1 & Median is 0.017721 \\
\hline$(-0.10)-(-0.05)$ & 0 & Maximum is 0.171805 \\
\hline$(-0.05)-(0,00)$ & 1 & Minimum is -0.177039 \\
\hline$(0.00)-(+0.05)$ & 2 & Std Dev. Is 0.129783 \\
\hline$(+0.05)-(+0.10)$ & 0 & Skewness is -0.173414 \\
\hline$(+0.10)-(+0.15)$ & 2 & Kurtosis is 1.644693 \\
\hline$(+0.15)-(+0.20)$ & 1 & Jarque-Bera is 0.733930 \\
\hline & & Probability is 0.692834 \\
\hline
\end{tabular}

Calculations made by the authors using Eviews7.

For a normal distribution, skewness is zero (normal distribution is symmetrical), and kurtosis is 3 . If the value is greater than 3 , then the distribution is leptokurtic, and if it is less than 3 the distribution is platykurtic. In this case, the mean is -4.7 , the median is 0.017 , the maximum is 0.17 and the minimum is -0.17 .

DOI: 10.24818/18423264/55.2.21.20 
Mircea Constantin Duică, Nicoleta Valentina Florea, Anișoara Duică, Dan Marius Coman

The skewness is negative (-0.173), and the kurtosis is 1,64 (being less than 3 the distribution is platykurtic). Jarque-Bera is testing if the distribution is normal. The test has as a null hypothesis: the distribution is normal. In our case, due to probability, which is greater than 0 , the null hypothesis is not rejected, thus the series is normally distributed.

\section{Conclusion and proposal}

We all have to know that sustainable consumption and production has theirs origins in the social, technical, economical and cultural context. Its impact determine the willingness to protect environment and limited resources. The sustainable consumption and production can be perceived as saving our different and diverse values, beliefs and traditions.

Starting with us, at microlevel (as a person and as an organization) may sustain green consumption and production, going beyond meso and macrolevel, globally as green believers. Consumption and production patterns have wide environmental impacts.

Sustainable production and consumption patterns use resources efficiently, respect resource constraints and reduce pressures on natural capital in order to increase overall well-being, keep the environment clean and healthy, and safeguard the needs of future generations.

The rise in living standards and the quality of life in Europe since the end of World War II has been made possible through increases in income, production and consumption, which so far have gone hand in hand with more resource extraction and growing pressures on natural capital (air, water, land and biodiversity) and the climate. Since we live on a planet with finite and interconnected resources, the rate at which they are used has relevant implications for today's prosperity and lasting effects on future generations.

The governments, in order to obtain a green behavior, must offer rewards for sustainable initiatives, must develop and apply green regulations in order to defend environment, and organizations to improve production by using social and ecological performance.

The organizations must see into the future, by ensuring future generations with green production and consumption and consumer must thing green, act green, behave green for them and for other to come.

Our study showed that between the analyzed variables, defined by EU as being components of sustainable consumption and production, there is a very high and positive correlation $(\mathrm{R}=0,938)$, thus they are influencing each other, thus important for the $\mathrm{EU}$ is to decouple economic growth and the improvement of living standards from resource use and the eventual negative environmental impacts.

This involves increasing the circularity of materials in the economy, thereby reducing both the need for resource extraction and the amount of waste ending up in landfills or incineration.

DOI: $10.24818 / 18423264 / 55.2 .21 .20$ 
The Relationship between Economic Activity and Green Production and Consumption at EU Level. An Analysis Based on Econometric and Information Models

It also means managing chemicals safely and shifting away from carbon-intensive energy carriers towards sustainably produced renewable energy sources. Such an approach would not only reduce environmental pressures, but also provide major economic benefits for every involved stakeholder.

\section{REFERENCES}

[1] Boucher, J.L. \& Heinonen, J. (2019), Sustainable Consumption, Promise or Myth? Case Studies from the Field, UK: Cambridge Scholars Pub;

[2] Dinulescu, R., Smeureanu, I., Dobrin, C., Popa I (2018), A Statistical Approach for Improving the Romanian Public Healthcare System Using the Lean Six Sigma Methodology, Economic Computation and Economic Cybernetics Studies and Research; ASE Publishing; Issue 3/2018; Vol. 52;

[3] Ekstrom, K.M. (2014), Waste Management and Sustainable Consumption; London: Routledge;

[4] Hara, Y., Yang, C.S., Isemura, M. \& Tomita I. (2017), Healths Benefits of Green Tea; UK: CABI;

[5] Iannuzzi, A. (2016), Greener Products: The Making and Marketing of Sustainable Brands, USA: CRC Press;

[6] Malyan, R.S. \& Duhan P. (2018), Green Consumerism: Perspectives, Sustainability, and Behavior, NJ: CRC Press;

[7] Mangla, S.K. \& Luthra, S. (2019), Sustainability, Innovation and Procurement; USA: CRC Press;

[8] Peiry, K., Ziegler, A. \& Baumgartner, J. (2016), Waste Management and

the Green Economy; USA: Edward Elgar Pub;

[9] Sang-Binge, T., Bin L. \& Yongian L (2017), Green Production Strategies for Sustainability, USA: IGI Global;

[10] Shmelev, S. (2016), Green Economy Reader; UK: Springer;

[11] Telesiene, A. \& Gross M. (2016), Green European; UK: Routledge;

[12] Thangasamy, E. (2017), Green Marketing and Environmental Responsibilty in Modern Corporations; USA: IGI Global;

[13] UN Environment Programme. Division of Technology, Industry and

Economics (2005), Advancing Sustainable Consumption in Asia,

UNEP/Earthprint;

[14] ${ }^{* * *}$ Sustainable Development in the EU, Monitoring report on progress toward the SDGs in an EU context, 2019, (accessed on 23.11.2019),

[15]***European Parliament and Council of the European Union (2009),

Regulation [1] (EC) No 443/2009 of the European Parliament and of the Council of 23 April 2009 setting emission performance standards for new passenger cars as part of the Community's integrated approach to reduce $\mathrm{CO} 2$ emissions from lightduty vehicles, as amended by Regulation (EU) No 333/2014. (accessed on 23.11.2019);

DOI: 10.24818/18423264/55.2.21.20 
Mircea Constantin Duică, Nicoleta Valentina Florea, Anișoara Duică, Dan Marius Coman

[16]***Environment, European Union, https://europa.eu/europeanunion/topics/environment_en (last updated Apr. 16, 2018), archived at http://perma.cc/MK9W-H3F4;

[17]***European Commission (2010), Being wise with waste: the EU's approach to waste management, Publication Office of the European Union, Luxembourg; [18]***The European Chemical Industry Council (2018), Facts and Figures of the European Chemical Industry Report 2018, p. 10. (accessed on 23.11.2019).

[19] https://ec.europa.eu/environment/green-growth/index en.html (accessed on 15.11.2019);

[20] http://www.sepa.gov.rs/download/publikacije/MoreFromLess MaterialResour ceEfficiencyEurope.pdf (accessed on 15.11.2019);

[21] https://ec.europa.eu/environment/action-programme/ (accessed on 15.11.2019). [22] https://ec.europa.eu/eurostat/statistics-explained/index.php?title=SDG_12_-

Responsible_consumption_and_production_in_the_EU:_overview_and_key_trends [23] https://ec.europa.eu/eurostat/databrowser/view/cei_srm030/default/table?lang= en (accessed on 20.02.2021);

[24]https://ec.europa.eu/eurostat/databrowser/view/nrg_ind_ren/default/table?lang= en (accessed on 20.02.2021);

[25]https://ec.europa.eu/eurostat/databrowser/view/t2020_33/default/table?lang=en (accessed on 20.02.2021).

DOI: $10.24818 / 18423264 / 55.2 .21 .20$ 